\title{
Erratum to: Life cycle, growth characteristics and host cell response of Rickettsia helvetica in a Vero cell line
}

\author{
Karin Elfving $\cdot$ Agneta Lukinius $・$ Kenneth Nilsson
}

Published online: 3 January 2012

(C) Springer Science+Business Media B.V. 2011

\section{Erratum to: Exp Appl Acarol DOI 10.1007/s10493-011-9508-7}

Due to an unfortunate turn of events, an incorrect version of Fig. 4 has been used in the above-mentioned publication. The correct image and its caption is published on the following page and should be treated as definitive by the reader.

The online version of the original article can be found under doi:10.1007/s10493-011-9508-7.

K. Elfving $\cdot$ K. Nilsson $(\bowtie)$

Department of Medical Sciences, Unit of Clinical Bacteriology, Uppsala University, 75185 Uppsala, Sweden

e-mail: kenneth.nilsson@medsci.uu.se

K. Elfving · K. Nilsson

Center of Clinical Research, Dalarna, 79182 Falun, Sweden

K. Elfving · K. Nilsson

Department of Clinical Microbiology, Falu Hospital, 79182 Falun, Sweden

A. Lukinius

Department of Immunology, Genetics and Pathology, Rudbeck Laboratory, Uppsala University, 75185 Uppsala, Sweden

K. Nilsson

Department of Medical Sciences, Unit of Infectious Diseases,

Uppsala University, 75185 Uppsala, Sweden 

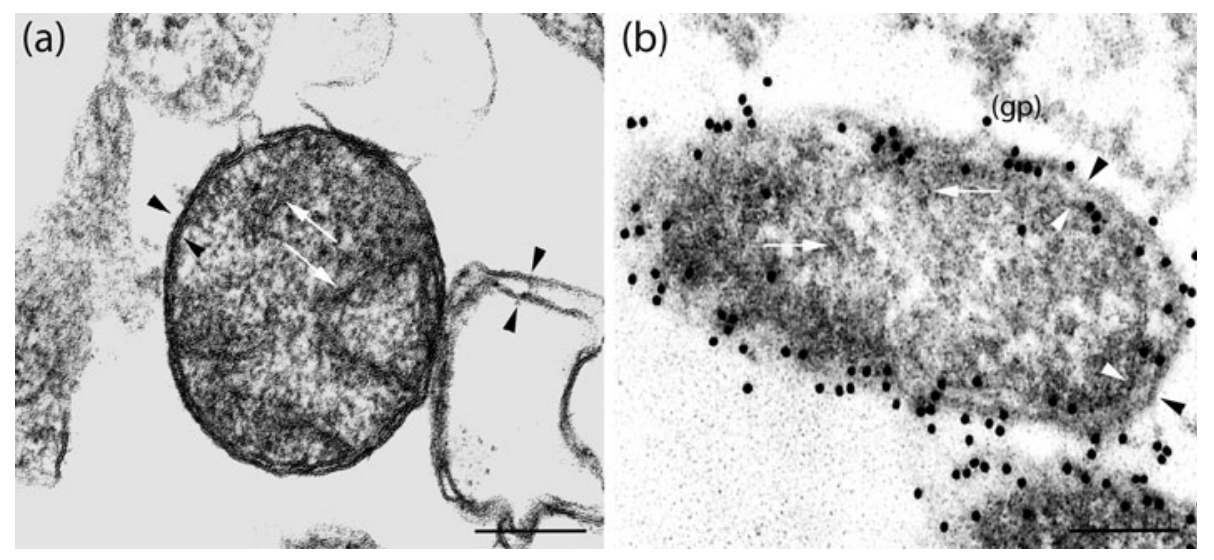

Fig. 4 Fourth to fifth day of Rickettsia helvetica-infected Vero cells. a Morphology of $R$. helvetica in partly decomposed host cells. Note the leaflets (arrow heads) and inner plasma membrane enclosing the periplasmatic space (ps). Fibrillate nucleic acid is clearly visible (long arrows) $\times 120,000$. Bar $150 \mathrm{~nm}$. b Anti-rickettsia antibodies with gold particles $(\mathrm{gp})(15 \mathrm{~nm})$ on Lowicryl-embedded cells. Leaflets and plasma membrane (arrows heads) and fibrillar nucleic acid (long arrows) are visible. The immunoreaction is mainly located along the membrane/leaflet part of the rickettsia but sparsely scattered all over the organism $\times 120,000$. Bar $150 \mathrm{~nm}$ 